\title{
EDITORIAL
}

\section{Meu ombro esquerdo}

Ariádne Scalfoni Rigo*

$\mathrm{E}$

screvi este editorial a poucos dias da sua publicação. Curiosamente, numa espécie de metalinguagem reveladora do universo da produção acadêmica, me dei conta de que precisava traduzir mais de cinco anos de uma transformadora experiência profissional, e pessoal, em poucas linhas. A princípio, pensei em continuar a discussão proposta no editorial anterior, sobre o processo de avaliação de artigos científicos, mas terei tempo e outros espaços para isso. Assim, decidi apenas compartilhar e registrar um pouco dessa vivência na "arbitragem do jogo da revisão por pares", como mencionou Raelin (2008). A questão é: por onde começar? Quais palavras, ou expressões, poderiam sintetizar esses cinco anos na editoria da revista O\&S? Num arroubo de humor com inspiração inglesa, fiquei tentada a traduzir a experiência a partir da presença de uma nova companheira da qual tento me divorciar ainda sem sucesso: uma dor no ombro esquerdo.

Entre o Pilates, sessões de RGP e doses de Dorflex, acabei pagando com a carne. Tenho encontrado muitos colegas de trabalho reclamando dos mesmos sintomas. Horas de computador - na universidade, em casa e em aviões - resultam em abaulamentos na lombar e protusões na cervical que, por sua vez, irradiam dormência e dores em algumas partes do corpo. Certa de que muitos leitores reconhecem a causa e esses sintomas, deixo aqui meu registro fisioterápico como ponto de partida.

Me despeço da editoria da revista O\&S com a sensação de dever cumprido e de experiência adquirida. Desde abril de 2014, quando fui convidada a compor uma equipe de três editores, o trabalho na O\&S passou a ocupar a maior parte da minha rotina. Já com alguma experiência em atividades editoriais, contribuí para colocarmos a revista em dia. Foram quase dois anos para atender a quase 400 autores ansiosos por respostas e ainda manter o fluxo ininterrupto dos processos editoriais. Isso feito, adiantamos a composição dos números a serem publicados em um ano. Paralelamente, a equipe conseguiu colocar

\footnotetext{
* Editora-chefe da Revista Organizações \& Sociedade. Doutora em Administração pela Universidade Federal da Bahia (UFBA). Professora da Escola de Administração da Universidade Federal da Bahia e do Programa de Pós-Graduação em Administração (UFBA/NPGA) - Salvador (BA), Brasil. E-mail: ariadne.rigo@ufba.br. ORCID: 0000-0002-3190-9968
} 
todos os 84 números já publicados (1993 a 2013) no novo sistema de editoração e enviar 672 artigos para a base SciELO nas linguagens exigidas. Desse momento em diante, os trabalhos de cerca de 2 mil autores e coautores poderiam ser encontrados facilmente na mais importante base de periódicos científicos do país. Ver tudo isso pronto foi recompensador.

No final de 2015, a revista já estava "em velocidade de cruzeiro", como disse um dos colegas da equipe, e poderia seguir viagem sem maiores percalços. A partir de então, eu e a talentosa secretária Tamires Lordelo seguimos "pilotando" a revista sozinhas. 2016 e 2017 foram anos em que pude revisar algumas políticas editoriais, inserir a revista em outras bases e, principalmente, buscar outras fontes de recursos. Além da fundamental parceria com o Ibepes, já mencionada em vários editoriais, a revista passou a obter apoios mais frequentes da Capes e do CNPq, por meio de editais. Os esforços contínuos para responder aos autores em prazos menores, juntamente com o suporte financeiro dos parceiros, nos permitiu publicar todos os números sem atrasos ao longo de mais de cinco anos. Fazer a revista funcionar foi minha grande recompensa, e me parece que é a de muitos editores.

Manter a tal velocidade de cruzeiro foi sem dúvida a tarefa mais difícil. No final de 2016, o cenário já se mostrava bem diferente de 2014. Especialmente duas questões despertaram minha atenção no dia a dia da revista. Uma delas foi o aumento da pressão por internacionalização. A outra foi a constatação de que o número de artigos e a variedade de temas submetidos à revista aumentaram sensivelmente. Com isso, mais artigos passaram a ser rejeitados.

Internacionalização. Essa palavra traduz quase toda a pressão sofrida por programas de pós-graduação e periódicos nacionais há algum tempo. Não é suficiente que uma revista esteja no mais alto patamar da avaliação da Capes no país. Ela também precisa ser internacional - e ser internacional significa ter autores e avaliadores estrangeiros - e estar presente em bases internacionais para ser lida (e citada) lá fora. Ou seja, deve ser publicada em língua inglesa. Vivi um curioso dilema até deixar a revista: os recursos públicos estavam cada vez mais escassos para periódicos não internacionalizados, ao mesmo tempo em que não havia recursos públicos para promover a internacionalização deles. Na realidade das Universidades Federais brasileiras, onde obter recursos para tradução dos sites e artigos se nem mesmo os editais para apoio a periódicos científicos permitem usar os recursos para isso? A estratégia adotada por algumas revistas foi "convidar" autores com artigos aceitos para publicação a custearem sua tradução para a língua inglesa. Resisti em adotar essa estratégia. Não achava justo que autores que submetiam seus textos em português, 0 idioma da revista, arcassem com a tradução depois do texto aprovado. Assim, publicamos em inglês o percentual mínimo exigido pelo SciELO, com os textos já submetidos nesse idioma. Em 2018, me vi num beco sem saída. Receosa da possibilidade de não atingirmos o número mínimo de artigos em inglês para aquele ano, solicitei aos autores a tradução dos artigos aprovados. Expliquei que não manter o mínimo de publicações em inglês significaria sair da base, e jogar fora o trabalho da equipe de 2014-2015 e dos editores anteriores. Para minha grata surpresa, quase todos se dispuseram a traduzir seus textos e ressaltaram o compromisso e o carinho com a revista. Ler todas aquelas mensagens foi reconfortante.

A segunda constatação foi que o número de submissões aumentou cerca de $20 \%$ de 2017 para cá. Sem publicar mais artigos por edição, principalmente por causa dos custos, as avaliações em desk review passaram a ser mais criteriosas e o escopo mais estreito. 
Inevitavelmente, o número de reprovações aumentou e, com elas, o de autores insatisfeitos. Administrar isso não foi fácil. Horas e horas lendo e relendo artigos e pareceres me ajudaram a tomar decisões mais adequadas para a revista no contexto, embora elas certamente tenham decepcionado alguns autores. Mesmo quando endereçadas a mim de forma pouco simpática, nunca me furtei em rever a trajetória de um texto no processo de avaliação a cada solicitação. Voltei atrás algumas vezes. Entre essas idas e vindas, devo confessar que ao rever uma decisão, de alguma forma eu também me revia. Refazia conceitos, repensava convicções. Alguns autores me afirmaram que humanizei o processo. Não estou certa disso, talvez estivesse mais próxima da máxima de Che Guevara: tentei manter a ternura, mesmo quando foi necessário endurecer. A ironia é que o tempo ia passando e a dor no ombro não mostrava nenhum sinal de recuo.

Comecei 2018 já sem fôlego para manter a velocidade de cruzeiro. Era hora de trocar a tripulação. Encontrar um novo editor e lhe passar o manche levou tempo. A viagem de pouco mais de cinco anos foi, ao fim, uma viagem de autodescoberta, tal como ocorre naqueles roadmovies clássicos. Agradeço ao colega Eduardo Davel por topar o desafio e desejo sorte nessa nova etapa do percurso. E, como sempre fiz, agradeço aos autores pelo interesse na revista, aos avaliadores pela dedicação e aos professores do Núcleo de Pós-Graduação em Administração (NPGA) da Universidade Federal da Bahia (UFBA) pela confiança depositada no meu trabalho.

Por fim, depois de fugir do padrão dos editoriais, é preciso apresentar, ainda que brevemente, os dois próximos números do volume 26 da revista O\&S. Publicaremos de uma só vez os números 90 e 91 de 2019 para encerrar o compromisso assumido em 2014. Ambos estão compostos por temas acadêmica e socialmente relevantes, privilegiados pela revista desde a sua concepção em 1993. As ideias centrais de alguns artigos mostram isso: escândalo, corrupção e a operação Lava-Jato; discriminação homofóbica e heteronormatividade no contexto organizacional; lógicas institucionais; razão substantiva; tecnologia e gestão social; psicologia social comunitária e América Latina; etnografia audiovisual e pesquisa organizacional; análise crítica do discurso e alternativa teórico-metodológica; lógicas decisórias e sustentabilidade; análise sociológica discursivo-imagética; economia do compartilhamento e economia do acesso e, coincidentemente, mudança e a emergência de novos atores.

Obrigada e boa leitura!

\section{REFERÊNCIAS}

RAELIN, J.A. Refereeing the game of peer review. Academy of Management Learning \& Education, v. 7, n. 1, p. 124-129. 2008. 